\title{
Small, high-tech back in business?
}

SmaLL high-technology business may have a bright future in the Soviet Union. Perestroika so far has changed the economic rules to allow for the creation of cooperative businesses, each of which will be owned equally by those who work for it. Some researchers are jumping at the opportunity.

Most attention hithero has been directed at the cooperative businesses springing up in agriculture and horticulture, often the source of goods sold in the free markets. (Family businesses are also now allowed.) But there are at least two technical fields that offer scope for entrepreneurship - the development of computer software and of diagnostic reagents derived by genetic manipulation.

That restrictions on business activity should have been lifted chiefly in respect of cooperatives is easily understood: one of the communists' objections to capitalism is that it enables individuals to exploit the labour of others. Cooperative businesses share the labour and the proceeds, but hitherto have not been encouraged. Even in the changed climate, people must stick with the jobs at which they are supposed to work, while the arrangements for providing cooperatives with working capital are still rudimentary. Nor does Soviet

such a small proportion of students. The problem-orientated olympiad system ("If you boil a turkey, why does the skin split in only one direction?", for example) requires that students should change intellectual gear. The school has taken to organizing summer schools to help highschool students appreciate its needs.

The school, of necessity residential, is essentially a finishing school, accounting for one or two years at the end of a student's high-school career. There is a girls' quota ("of course, they're weaker in the olympiads"), although Lavrentiev names some of the young women who are doing well at the university.

The school seems less dismayed than it might be at the decision of a small proportion of its students to quit after a month at Novosibirsk, on the spartan grounds that, whether the decision springs from nostalgia (homesickness) or dismay at being a small fish in a large pond, it shows the defectors to be "unfitted for a scientific career".

The curriculum at the special school is no different from that of the past two years at any Soviet high-school, Lavrentiev says. Students will, for example, be taught calculus, but will not be expected to evaluate $\int \mathrm{e} x^{2} \mathrm{~d} x$, for example. The objective is simply to give them a more thorough grounding in their subjects.

The school has been running computer classes since 1972 , but has only recently made them generally available. And there law makes provision for the indemnity from creditors that follows from incorporation in the West.

The origins of the mini-software houses (there are said to be half a dozen in Moscow) are easily imagined. People simply use the computers at their workplaces, but out of working hours, to develop novel or customized software, which they then sell on to customers with whom they have made a deal. Strictly, the institute or other institution should be told of the arrangement, and may in turn require a share of the proceeds.

The molecular diagnostics cooperative being organized in Moscow is more unusual, involving roughly a score of people already. The objective is to identify and then to clone potential biological reagents, bacterial and viral antigens for example. The customers would include those physicians still engaged in private practice.

At least one potential member of this consortium was in two minds, earlier this month, about an invitation to join this consortium. The meeting he had just attended had left him with the impression that the organizers were "simply concerned with making money". He planned to think the offer over.

remains a great shortage of equipment, with the result that students do not have ad lib access to computers. Lavrentiev acknowledges that the school may have to strengthen its teaching of biology.

Links between the school and the rest of Novosibirsk's scientific enterprise are close (although some are mystified that the school appears not to have been sending its students to visit the nuclear physics institute). Some 35 institute researchers have teaching responsibilities at the school, despite the inconvenience caused by their frequent business trips.

Graduates from the school account for 40 per cent of the physics and 25 per cent of the mathematics students at the university on campus. Lavrentiev himself says with pride that his career has taken him through the whole cycle, from school to university to Nuclear Physics Institute and back to the school.

So is the school one to which one would wish to send one's son or daughter? The students themselves, who are as bright as paint, say they enjoy the atmosphere and the competitiveness. One says that she has found it helpful to be given this reminder that she may not be as good a scientist as she had thought. Given that Novosibirsk is a good place at which to practise science (and that Moscow and Leningrad are inaccessible), why not? The arguments in the other direction are merely the spartan life, the loneliness and the isolation, but there is a lot of that in the Soviet Union.
Publishing

\section{Is opportunity durable?}

MIR (which means "world") Publishers, one of the largest operations of its kind anywhere, is adapting to glasnost with enthusiasm but uncertainly. Most of the company's business is the translation of 200 technical books from English into Russian and the translation of 300 books a year from Russian into several other languages. Vladimir Kartsev, director of the company, explained earlier this month that glasnost has provided opportunities not yet fully grasped.

In the old days, Kartsev says, the company was "told" what books to publish; with the help of 700 employees, it discharged its obligations and earned a surplus of about 2 million rubles a year. Now, the company has to decide for itself what books to publish and can negotiate with the publishers of English-language books on the price it will pay for translation rights. But domestic prices, those at which it may sell its products, are still controlled, so that the company has to find some substitute for what would be called a market in the West.

The solution is a system of "readers" conferences". Potential readers are brought to the park-like headquarters in suburban Moscow to say what kinds of books they would like to read, or would find most useful (reference books and books on computers predominate).

What about the books sold on in the other direction? Mir says that "frankly, we have no direct experience" of the wheeling and dealing that passes for publishing in the international market. But, by now, Kartsev and his colleagues may have learned a little from their first visit to the Frankfurt Book Fair earlier in the month.

Kartsev and his colleagues have a few simple ambitions. They want to be able to price the books they publish more flexibly, usually charging more. They think they could reduce their workforce by a half without loss of production, demanding more from people instead. They would like to make it possible to reduce the time taken for publication (they are in their printers' hands) from three years to something much less. (A Compugraphic desktop publishing system is being played with in a shed in the grounds, perhaps pointing the way to that ambitious goal.

Meanwhile, everybody considers what money Mir might have made had not Pergamon Press secured the rights to publish Landau \& Lifshitz in English. But Mir stands to do as well from its decision to publish Scientific American in Russian, an operation fronted by Professor Sergei Kapitza and run by Mrs Lidiya Shepeleva. 